\title{
The "Refugee Crisis" as a Eurocentric Media Construct: An Exploratory Analysis of Pro-Migrant Media Representations in the Guardian and the New York Times
}

\author{
Maria Avraamidou \\ University of Cyprus, Nicosia, Cyprus, mariaavraamidou@gmail.com
}

\begin{abstract}
This article presents a critical analysis of how two elite media publications in the United States and the United Kingdom, the New York Times and the Guardian/Observer respectively, represented the so-called European refugee crisis in their editorials. The study foregrounds a media aporia of why Europe did not abide with human rights and democratic values vis-à-vis the refugee drama and a subsequent nostalgia for a European past of democracy and transnational unity that never really existed. These media representations, although sympathetic towards migrants, are inherently Eurocentric, helping to reproduce the existing repressive global migration regime because they do not see the crisis as a continuation of its coloniality but as a rupture.
\end{abstract}

Keywords: international media, refugee crisis, migration, Eurocentrism, qualitative media analysis

Acknowledgement: This work was supported by the Cyprus Research Promotion Foundation, Grant Agreement: POST-DOC/0916/0115.

\section{Introduction}

The mediated images of the wretched of the earth (Fanon 1967) in forced mobility from the Global South to securitised European territories particularly in the summer and autumn of 2015 led to a discussion about an existential crisis in Europe (Popescu 2016) and the limits of Western cosmopolitanism and humanism (Huggan 2008). Events boosted scholarly interest in the media/migration nexus. Scholars explicated the moral panics created by populist media around an animalistic and racialised other (Gutiérrez 2018) and traced the diffusion of binaries of 'us' versus the migrant 'other'. The so-called "liberal quality media" (Van Dijk 1995, 17) were found to be more sympathetic towards migrants and refugees (Berry, Inaki and Moore 2015) versus the blatant racism and xenophobia of the extreme right media. Overall, traditional media and social media across Europe moved between securitisation and humanitarianism, focusing either on our safety or on their human rights respectively (Siapera et al. 2018). Despite problematising both humanitarian and securitisation media content, studies rarely delved into the meanings and ideologies that underpinned seemingly positive media migrant content. Importantly, studies rarely employed concepts such as imperialism and colonialism to problematise the media/refugee nexus (Khiabany 2016) but remained at ease by scrutinising an orientalist media gaze (Chouliaraki and Zaborowski 2017). But, as Khiabany $(2016,2)$ argues, these events and their media coverage "ha[ve] everything to do with place, history, class, capitalism and imperialism". It is this research vacuum that this article aims to address. 
Considering the European migration question as a global question of race and postcoloniality (De Genova 2016) and the recent refugee crisis as an inherent part of Europe's ongoing border crisis (De Genova 2017, 9), this study is interested in media content on the said period and has looked for that content in established, quality media of the United Kingdom (UK) and the United States (US) sharing an internationalised, online readership - the Guardian and the New York Times respectively. The overarching aim is to problematise media power accounting for media content, what we learn from the media (Ott and Mack 2014). Therefore, this article provides exploratory answers to the question of how elite, influential media represented the European refugee crisis on their online sites. Subsequently it problematises the ideologies that underpin these representations and unsettles the predominant liberal media framing of the events as a humanitarian crisis, demonstrating the inherent Eurocentrism of this framing.

\section{Theoretical Approach and Research Rationale}

The current study, situated in the field of critical media studies (Fuchs 2016; Mejia, Kay and Sullivan 2018), uses the insights of critiques on Eurocentrism (Amin 2009) and takes a critical approach to European and global migration (see for example De Genova $2010 ; 2016 ; 2017)$ to study media representations of the so-called 2015 refugee crisis. In doing so, it links these representations to the broader debate on migration and examines the ideologies they carry, which can have consequences on the material world. In effect, as argued, communication can take different ideological forms which aim at advancing specific interests promoting the construction of certain groups as enemies (Fuchs 2016, 13). In an era of intense contradictions ${ }^{1}$ and global inequalities the mainstream media, national and international, are not expected to completely silence existing contradictions and conflicts (Fuchs 2016) but to represent different sides of debates and specific understandings. They are mainly sites for "the conventional ideas of insiders" (Croteau and Hoynes 2014, 164) to struggle in meaning-making processes that can shape perceptions and in effect build consensus around the existing order of things and of inequalities based on class, race, gender or sexual orientation. In effect, mainstream media offer predominant ways of understanding the world we are living in, and they maintain the social order rather than challenge it (Hall 1982).

Nevertheless, this study adopts a perspective that acknowledges that not everyone consumes media content uncritically, but as noted:

In essence, "ideas only become effective if they do, in the end, connect with a particular constellation of social forces." This does not mean that everyone who operates within a shared space of subjectivity will interpret a given message the same way, but rather, that the material conditions of which these social forces are a part can help to "explain why certain views, and not others, gain social currency among the various social classes" (Mejia, Kay and Sullivan 2018, 112).

The present study understands that the foundations of contemporary migration patterns stand on European colonialism (Massey 2000) and that they continue to reproduce its racialisation and logics through inclusionary and exclusionary practices

${ }^{1}$ Mobility in capitalism is inherently contradictory as, whereas free movement of labour and persons is promoted (e.g. within the EU), physical and digital barriers are still constantly erected globally (Trimikliniotis 2020). 
(Gutiérrez 2018). Their discussion from a critical standpoint should involve a consideration of colonialism's history as "a multilevel process of taking land and resources" operating simultaneously at the level of consciousness (Cashmore 1996, 82) and of discourse (Said 1978) from the perspectives of its victims and not its perpetrators (Young 2001, 4). Despite colonialism's heterogeneity, its logics, practises and effects shared striking similarities of violent geographies (Said 1978; Fanon 1967) underlined by Eurocentric values (Amin 2009), capitalist modes of production (Young 2001) and a discourse of domination, delineated as Orientalism, of a Western style over the Orient (Said 1978) which have evolved but certainly not disappeared in the postcolonial world (cf. Silverstein 2005). As with colonialism, imperialism involves subjugation of one people by another (Young 2001, 15) but, unlike colonialism, imperialism in its broader understanding has yet to end (Young 2001, 27). Both are part of the dynamic of capitalism in its "global trajectory" (Lazarus 2011,7), particularly racial capitalism. To clarify, racial capitalism is not another type of capitalism: capitalism is racial capitalism (Melamed 2015), characterised by "the process of deriving social and economic value from the racial identity of another person" (Leong 2013, 2152). More and more, "contemporary racial capitalism deploys liberal and multicultural terms of inclusion to value and devalue forms of humanity differentially to fit the needs of reigning statecapital orders". (Melamed 2015, 77). Eurocentrism, as an ideology which departs from a theory of world history and implies a global political project obscures capitalism and its modes of production, making it appear, in the words of Amin (2009), as transhistorical and rational. Additionally, Eurocentrism promotes the uniqueness of European history or the European capitalist miracle and, finally, it makes inequalities appear inter$\mathrm{nal} /$ national, hindering recognition of how the centre/periphery polarization is systemic (Amin 2009). Overall, Eurocentrism has three significant elements (Quijano 2000):

1. It is characterised by core dualisms such as capital/pre-capital, Europe/non-Europe, primitive/civilised, traditional/modern and evolutionism, that is, from a certain state towards a modern European society;

2. Cultural differences are conflated with the category of race and are naturalised;

3. The distorted-temporal relocation of all those differences is achieved by relocating non-Europeans in the past.

There can be banal manifestations of Eurocentrism, for example in embodied practices like banal orientalism (Haldrup, Koefoed and Simonsen 2006). The orient other is constructed as sharing "immutable traits defined in simple opposition to the characteristics of the Occidental world" that can go unnoticed (Amin 2009, 175). European and broadly Western values and ideals may appear in Eurocentric ideology as natural and fixed, connoting for example equality and democracy, but they have always been ambiguous and contradictory, as the critique of enlightenment - its limits and contradictions - has shown (Adorno and Horkheimer 1997): particularly in revealing its role in justifying, through "reason", violence and genocide outside and within Europe (Adorno and Horkheimer 1997; Dussel 2000; Virdee 2019). For example, racism is an inherent part of the making of Europe (Virdee 2019) but this, in Eurocentric constructs of a civilized West/Europe, is forgotten. The EU migration regime embodies the dialectic of enlightenment (Adorno and Horkheimer 1997); namely, its inherently contradictory universal values that arguably sustain the European project but at the same time undermine it. In particular, EU migration policies are shaped by the interconnections between racial capitalism and coloniality despite declarations to respect human rights for all. EU asylum and migration policies are criticized for becoming a new way of regulating and 
controlling racialised labour migration (Gutiérrez 2018, 25; Rajaram 2018). Racial capitalism coupled with securitisation and the politics of antiterrorism exemplify contemporary migration in Europe as a problem of integration, particularly of Muslims, who are an increasingly racialised class (De Genova 2016). Migration as a problem of the integration of unworthy others promotes nativism (De Genova 2016, 80) and the nation is communicated as being threatened by "aliens" (Fuchs 2019, 5). The Oriental East, which is contemporary Europe's most prominent threatening external other, replaced communism and is increasingly coupled with hostility against Muslims (Haldrup, Koefoed and Simonsen 2006). These Eurocentric approaches to migration reproduce the invention of the eternal West and its Oriental other (Amin 2009). Humanitarianism that informs a pro-migrant response promoting a human rights culture can also be inherently Eurocentric, "bringing together the well-being of the West with the hardships of the global south" (Douzinas 2007, 11). That is, it reproduces the idea that "They, the savages/victims, make us civilised" $(2007,12)$, which is associated with the civilising mission of Christian missionaries aiming at saving colonised people with Christianity (Cashmore 1996, 82). Therefore, practices coupled with predominant discourses reproduce colonially instigated perceptions about the West or the Global North's civilisation mission towards migrants from the East (Gatt et al. 2016).

The question to answer is how structurally powerful media online may contribute to this reproduction rather than challenge the migration regime for the benefit of the usual suspects, those who are in power and benefit from its existence and reproduction.

\section{Methodology and Method of Analysis}

This study's exploratory methodological approach was guided by a central research question, namely how elite, influential international media represented the European refugee crisis in their online sites. This question was specified during the recursive analysis (Braun and Clarke 2006) in order to provide a problematisation of the seemingly pro-migrant media content.

The interest of the study was purposely not on fierce forms of anti-migrant media content, already scrutinised in research, but on so-called quality or liberal media. This is because the liberal media's ideological role in the meaning-making processes around migration, unlike the often self-evident role of the populist and extreme rightwing media, could go unseen. The focus is on elite international media because they remain robust global players on international news dominating the world wide web (Paterson 2007). As noted, "even quality journalism is succumbed to the logics and rationales of neoliberalism" (Mylonas 2015, 252). This study provides a much-needed trans-Atlantic view of how powerful media in the liberal spectra represent migration from the Global South to the Global North and, in this way, contributes to the literature on the media/migration nexus, which is currently fragmented and dominated by small case studies or regional comparative quantitative approaches lacking a comparative qualitative insight. It focuses on two globally influential media organisations: the American New York Times (the NYT) and the British The Guardian/Observer (the Guardian), who share a significant online global readership. The NYT is an important source of international news and an elite voice in various matters (Sassen 2001), consistently covering immigration topics (Suro 2009). The Guardian focuses on how to respond to the crisis and scrutinises Europe for inadequate rescue operations while briefly noting the positive contribution of migrants in receiving countries (Berry, Inaki and Moore 2015). 
The focus is on editorials, which demonstrate the media institutional ideological viewpoint. This has an inherent limitation as both media organisations may have hosted a variety of representations beyond those circulated in their editorials: these could be the focus of further research.

The period of focus is between 2013 and 2015 to ensure a richer sample than by focusing merely on the peak of the events in 2015. Most editorials were published in 2015. In 2013, only one editorial in the Guardian revolved around the "Syrian crisis"/refugees whereas the rest reflected on migration as a national matter, or on intra-EU migration. The same year, the NYT published one editorial on the "Syrian Refugee Crisis". In 2014, both newspapers had two editorials focusing exclusively on the "European migration crisis"/Syrian refugees but the Guardian published another two on migration in general. In 2015, 16 editorials by the Guardian and 12 editorials by the NYT dealt with migration and refugees, with the majority of them focusing on the socalled European Refugee Crisis. Overall, a search on the online sites of the two newspapers using the same keywords (refugee, migrant and refugee crisis) between 1 January 2013 to 31 December 2015 provided 15 editorials by the NYT and 27 by the Guardian. From these, those focusing on very specific national issues (e.g. on Cuban migrants in the US) were excluded as irrelevant. The final data set consisted of 13 editorials by the NYT and 27 from the Guardian.

The data set was stored and coded in Nvivo. The codes and sub-codes were derived through the analytical process. In effect, each code represents an actor:

1. countries/states (e.g. country of origin of migrants/refugees, the US, etc.)

2. Europe considered as the European Union or in broader terms

3. various groups (e.g. military/paramilitary)

4. entities in geographical terms (e.g. the Balkans, West/East)

5. refugees

6. migrants

7. entities defined in cultural/religious terms (e.g. Arab World)

8. international organisations

9. people/society

10. media

11. other actors (e.g. traffickers)

The sympathetic approach towards refugees/migrants became evident early on. In line with the research question it became analytically interesting to see how Europe was linked with codes such as that of West/ East to shape meanings around the events. In effect, the question of how these media organisations represented the border crisis became a question of how they represented Europe, the West/East, and what Europe and the West are - the values and beliefs that underpin them and their implications. Therefore, the subsequent analysis is inter-code and arose mainly from the following codes and sub-codes: Europe, geographically defined actors (West, East). In the end, I returned to the editorial under analysis, in which extracts appeared, to ensure that a reported theme which arose from the said codes was consistent with the editorial as a whole. In the analysis, media extracts are noted to better foreground the arguments made. 


\section{Analysis}

\subsection{Europe's Liberal Dilemma}

The editorials studied recurrently represented Europe as facing a moral dilemma, particularly during 2015, and failing to respond humanly and deal effectively with the influx of people moving irregularly towards or already within its territories.

The Guardian's editorials referred to a Europe of values and named these high values as democracy and human rights. Therefore, the inability to deal with the crisis put at stake the fundamental values underpinning the European project, representing Europe as undergoing an existential crisis. It characteristically noted:

The refugee crisis, the tip of an almost unprecedented human migration from south to north, faces the EU with a moral challenge that it is proving ill-equipped to meet. The Europe of values, reflected in the obligation for countries applying for EU membership not just to meet economic tests but to have democratic institutions and a proven respect for human rights, is under strain. Economic recession, the threat of terrorism and the rise of the extreme right are all weakening its institutional underpinnings: high ideals are always at risk from low politics. But this is no abstract question. It is an all-too-real disaster for hundreds of thousands of Syrians and others who are fleeing war and persecution and have endured perilous journeys to reach the southern fringes of Europe. It could also be dangerous for the EU itself.

The NYT also expected Europe to show compassion as a Western liberal actor with, as claimed, a tradition in offering refuge to the world's hunted and miserable (September 15, 2015; December 4, 2015) and called wealthier nations to offer refuge to the displaced. This is an example:

It's possible for wealthier nations to anticipate the continuing waves of displaced people and to shape long-term, orderly ways to help them weather the upheavals in their homelands or, if it becomes necessary, to help them settle in new lands, the way many of our parents and grandparents did (NYT, June 13, 2015).

Evidently, the responsibility of wealthier nations and of Europe towards the displaced is a humanitarian one: to relieve the woes of those who suffer, either through exporting good governance to their turbulent homelands or offering them protection when they arrive (Douzinas 2007). The same editorial also noted that "Unfortunately, it is only when the human tide overflows its Third World boundaries, like the boatloads of Africans trying to cross the Mediterranean into Europe or the Syrians trying to cross from a refugee-saturated Turkey into Greece or Bulgaria, that the rich nations begin a panicky search for remedies" (June 13, 2015). This can be read as a self-critical instance given that the outlet is a powerful voice of a rich nation.

Both newspapers represented Germany and Sweden as generous, praising Chancellor Angela Merkel for welcoming refugees and therefore for defending European ideals. The Guardian noted that Germany proved more willing than others, including Britain, to open up to refugees (September 1, 2015) and the NYT underlined that "only Germany and Sweden have responded in a generous way" (December 13, 2014). This reflects how Germany largely received global praise at the time for its humanitarianism despite being the "architect and driving force of that very (migration) regime" (De Genova 2017,13 ). Simultaneously, media accused former communist countries and specifically their leadership of boycotting efforts for a European, humanitarian reaction. An 
NYT editorial titled "Eastern Europe's Short Memory" is indicative of this understanding:

The tragic reaction was all the more shameful because those most adamantly opposed to quotas were some Eastern European countries that recently basked in and richly benefited from the embrace of their Western neighbors. These developments should be especially worrisome to the Eastern Europeans. Their inability to travel freely was an agonizing aspect of their decades under Communist dictatorship, and the generous welcome they received when they rejoined the ranks of Western liberal democracies was a great triumph for all of Europe. It would be a tragedy if those same eastern countries now contributed to the unraveling of European unity, just when it is so desperately needed. (September 15, 2015)

Eastern Europeans are represented as people who had long lived on the wealth of the West but have yet to fully endorse Western ideals, and threaten to break up Europe. In this way, normative ideas on European identity defined in opposition to Eastern Communism are reproduced (Haldrup, Koefoed and Simonsen 2006, 174). The Guardian questioned the merits of EU expansion to include former communist countries and wrote that "In a refugee crisis of unprecedented proportions, Hungary's prime minister, Viktor Orbán, has set himself up as a bulwark against a generous-spirited, pan-European approach" (6 September 2015). It concluded that "EU institutions have failed in the past to hold him accountable for trampling on Europe's values - now is the time to do so". In this context, the evildoer is a European member-state while Europe remains the moral rescuer of desperate Syrians. So, humanitarianism is used to demarcate the borders between genuine, liberal Western states and anti-democratic ones. In another editorial, the Guardian divided Europe into old and new, driven by earlier statements of Hungary's Orbán that he was defending European Christianity against a Muslim influx. This is an extract:

While original EU-bloc countries such as Germany, Italy and France have backed a common European response on migration and asylum, there has been strong opposition from newer members in the east such as Hungary, Poland and the Baltic states: just last week, the Hungarian prime minister made incendiary comments about the refugee crisis threatening Europe's status as a Christian continent. These growing fissures between old and new Europe risk undermining the momentous achievement that was Europe's eastwards expansion and demonstrate how, in retrospect, European leaders could have prioritized the broadening of the union over its deepening (September 6, 2015).

Evidently, the explicitly anti-migrant stance of the leadership of certain countries provided an alibi for Europe's concurrent inability to respond in a spirit of unity and humanitarianism to the crisis. In this binary, it is Western Europe that encompasses the genuine ideals of Europeanness (e.g. democratic values, respect for human rights) whereas Eastern European countries represent intolerance and totalitarianism despite the fact that other EU member states, and not just the so-called Eastern Europeans, were also discussing fences to keep migrants out (see Rheindorf and Wodak 2018 for Austria). Notably, it is an inherently Eurocentric thesis of other societies as inferior at levels of wealth and in terms of democracy (Amin 2009). However, Eastern Europeans, accused in both publications for being xenophobic and sabotaging a generous European reaction to refugees, also constitute Europe's cheap labour. This is a convenient 
absence: that Eastern Europeans served as cheap labour, causing lower salaries across the EU, and that intensified privatisation in their countries led to the dissolution of security schemes that in turn contributed to the rise of populism and the far right (Davison and Shire 2015).

Editorials attributed Europe's inability to act in a humanely generous way to the recent economic recession, the threat of terrorism and the rise of the extreme right and of populism. In this context, Europe was sketched as xenophobic, facing a rise of populism and of anti-migrant sentiments among its people. The following is a characteristic extract:

It would be naïve not to recognize that this great moral challenge is also a fraught political challenge. In the context of the rise of an anti-migrant right across the EU, it is understandable that the main political parties recognize and try to respond to voters' anxieties. But that is not the same as adopting the policies of the xenophobes (Guardian, October 28, 2014).

This rise of populism and anti-migration sentiments among Europeans - real or false - appeared in the studied newspapers as another alibi for the EU leadership's paralysis before events. For these newspapers, mainstream politicians wanted to reassure their electorate that they would not take measures in favour of migrants at their expense. People en route are represented as victims of an intra-European conflict between the good (e.g. democracy, solidarity), an idiom of the genuine, original Europe, and the evil (e.g. fences, repression, xenophobia), fuelled by a recurrent understanding that EU leadership feared to show generosity to refugees because populist politicians would seize the opportunity to spread xenophobia and subsequently make political gains. Editorials, in a way, legitimised anti-migrant stances because of the rise of populism: Europe wanted to do more for refugees but could not.

In some instances, editorials also blamed EU migration policy for the continuation of the crisis. The Guardian criticised the EU for not taking adequate measures or showing internal solidarity (known as burden-sharing) but did not delve into full-scale criticism apart from sporadic references that Europe failed to deal with the causes of migration and was turning a blind eye to repression in certain regimes (e.g. Eritrea). The Guardian saw the decision to end the Mare Nostrum ${ }^{2}$ project as a betrayal of Europe's fundamental principles, the result of incapable politicians:

What a grotesque betrayal of the founding principles of the EU, an organization built on the promise of peace, prosperity and asylum for the desperate. What an indictment of timid politicians. (Guardian, October 28, 2014)

The NYT was more critical as to why the EU was failing as it also attributed that failure to the EU migration policy (e.g. the Dublin regulation). Editorials, when they spoke of solutions to the migration issue and the crisis, underlined the need for legal channels for people to claim asylum in EU countries, and proposed more rescue efforts at sea and anti-trafficking measures along with assistance for the development of other regions.

Regarding Europe's past, the Guardian referred to the "never again" campaign. The Holocaust was once more used as "the universal standard of comparison, and the

${ }^{2}$ A military-humanitarian operation in the Mediterranean for rescuing migrants and arresting smugglers (see Musarò 2017). 
measure of evil" (Douzinas 2007, 21). This is an extract building on relevant statements by Merkel:

But Mrs Merkel has sent a timely signal that the lowest instincts must now be confronted. She has reminded Europe that it was built on values, including the imperative of "never again", which flows directly from 1930s memories of Jewish refugees from Germany and Austria being shunned by other nations. Some will see other special reasons why Germany is proving more willing than others to open up to refugees, such as a rapidly ageing population, which strengthens the economic benefits of inward migration. But don't dismiss Mrs Merkel's indisputable point, which is that Europe must come together on a strategic issue that cannot be wished away (September 1, 2015).

References to "never again" allude herein and elsewhere in the Guardian to memories of the Holocaust interwoven with European ideals and subsequently with European identity. With "never again", European countries declared their will to work in unity and prevent a new bloodshed among them. The Holocaust is a powerful symbol in collective memories in the West but also beyond, used to criticise not merely anti-Semitism but also other crimes against humanity (Baer and Sznaider 2015). It was also used to defend open border policies in mediatised discourse in Austria during the 2015 summer (Wodak 2018). Overall, references to "never again" seem to serve two aims: first, as a moral basis to call for internal solidarity and unity (e.g. to prioritise common good over national interests) and second, to persuade key actors that more atrocities should be prevented. Simultaneously, it creates a nostalgic longing for united Europe's origins. Subsequently it is a cry to protect certain values associated with liberal democracy - it is a cry perhaps to keep alive the last utopia of our times, human rights (Moyn 2012). But this absolute comparison of the past versus the present is based on selective memories, particularly given that the West's commitment not to repeat atrocities is highly controversial and, as elsewhere noted, "never again" is a promise broken multiple times since it was made (Askin 2005).

Editorials clearly proposed that Europe had to respond as a humanitarian, moral rescuer towards helpless victims suffering atrocities, an expectation based on the alleged principles underpinning Europe.

\subsection{Numbers Game Discourse and Utilitarianism}

Recurrent references to an almost unprecedented migration movement reflect how a numbers game discourse was used at the time to persuade decision-makers to take positive measures.

Media spoke about a "continuing waves of displaced people" (NYT, June 13, 2015), a "refugee crisis of unprecedented proportions" (Guardian, September 6, 2015) or underlined death and displacement tolls such as that the Syrian conflict had "killed more than 250,000 people and caused millions more to flee the country" (NYT, October 29, 2015) to ask international actors to coordinate to offer a solution. They recurrently noted similar alarmist numbers, for example that "Hundreds of thousands are fleeing war zones and persecution in Europe's worst refugee crisis since the second world war" (Guardian, September 1, 2015) and repeated the refugee or migrant death toll in the Mediterranean or elsewhere in Europe. The Guardian for example noted that "Meanwhile, at least 20 bodies have been found in the back of an abandoned Hungarian truck on an Austrian motorway, to add to the bodies of at least 50 migrants found on a boat making the crossing to Italy from Libya" (August 27, 2015). Numbers were 
also essential to mobilise support to southern member-states such as Greece: "The refugees, arriving in Greece at a rate of 1,000 a day, are exhausted, dehydrated and hungry" (NYT, August 6, 2015). Notably, the source of alarmist numbers often were international organisations like UNHCR: "The United Nations is predicting that 3,000 refugees per day will soon pour into the Balkans", the NYT noted emphatically (August $28,2015)$, while in another instance it concluded:

On Friday, the United Nations called on the European Union to take in 200,000 people under a binding emergency relocation program, and to set up large reception camps in Italy, Greece and Hungary. The European Commission must act swiftly to ensure that ministers meeting in Brussels on Sept. 14 to deal with the crisis respond to these demands - before the emotions triggered by the photos fade and more people die (September 4, 2015).

Relevant alarmist numbers were aimed at raising sympathy (see also White 2019), in contrast to the numbers game discourse used in anti-migration rhetoric to falsely alarm the public that numerous third-country aliens arrived or would arrive in their nationcountries to pose an economic and cultural threat (see Van Dijk 2000). Arguably, this discourse is false because it is simply not known if by comparison more people were displaced then than now, and dangerous because it is abstract and therefore "risks decreasing, not increasing, public sympathy and support" (White 2019). Recurrent emphasis on the numerical side of suffering is also dangerous because by speaking of record deaths, for example, the media constantly shift the standard for which a humanitarian response is necessary higher and higher, while repetitions of the death toll can lead to humanitarian fatigue, normalising an atrocity as banal rather than creating sympathy.

These media organisations considered that the number of people en route to Europe or already there was especially high. Still, they did not consider, as populist media did, that this legitimised border closure, instead trying to cast migrants in non-threatening terms drawing from a common line of arguments in favourable media representations of migration and utilitarianism (Kadianaki et al. 2018). This is explicated in phrases such as "Europe needs immigrants" (Guardian, November 12, 2015) or in editorial titles such as "Europe Should See Refugees as a Boon, Not a Burden" (NYT, September 18, 2015). The following is an indicative NYT extract of migrants positioned as contributors to the hosting society's economy:

Even a large influx of immigrants does not mean fewer jobs for the existing population, since economies do not have a finite number of jobs. Immigrants often bring skills with them, and some start new businesses, creating jobs for others. The less skilled often take jobs that are hard to fill, like in child care, for example, which allows more parents to work. A working paper published last year by four economists found that immigration benefited local populations in 19 of the 20 industrialized countries they studied. Another study found that an influx of refugees into Denmark in the 1990s led native workers to switch to more skilled jobs and away from jobs that were mostly manual labor. As a result, some local workers earned higher wages. (September 18, 2015)

Evidently, cheap migrant labour does not imply, as in anti-migrant discourses, stealing jobs. But despite references to migrants as business wo/men the most predominant expectation is that they constitute unskilled or semi-skilled workers. Simultaneously, Europe was sketched as ageing and in need of migrants described as "future taxpayers 
who will support an ageing population" (Guardian, 12 November 2015). However, this is still a form of utilitarianism which reproduces the racial division of colonialism in which the Westerners exploit the Oriental subject, albeit with mutual benefits. This recalls the Smithian belief that egoism is solidarity, as by being benefited, wealthy Western countries also help others (Harari 2011, 320). So, migrant contribution is directly linked to the capitalist mode of production - the basis for claimed European superiority (Amin 2009). Importantly, the relevant notion of equality was used mainly in relation to burden-sharing across the West rather than in relation to the treatment of migrants. This is perhaps because at the time, the reception of migrants was a priority so as to prevent more deaths. Nevertheless, it is another idiom of Eurocentrism to marginalise the principle of equality (Amin 2009).

Another obligation was to educate migrants to become useful to their new country and their country of origin (Guardian, 25 August 2018). Evidently, the burden of the white man towards "Your new-caught sullen peoples, - Half devil and half child" (Kipling 1899) remains essentially the same as coincided more than a century ago, also feeding a utilitarian media approach to migrants and refugees. This is maintained despite the fact that it is not Europe that is re-making migrants but its migrants who make Europe anew (De Genova 2016, 78), forming a real force of change (Trimikliniotis 2020).

\section{Discussion}

The pro-migrant media approach to the events tapped into popular sentiments that seemingly require no explanation, e.g. the conviction that Europe is democratic and respects human rights. Yet social and political currents appeared to contradict common-sense ideas. The Guardian editorials especially appeared in extreme difficulty in establishing the theoretical truth that Europe is committed to universal values of democracy and human rights. This difficulty arose by the existence of evidence both in favour of that truth and against it; Europe was an "obscure object of desire" (De Genova 2016, 76) not only for migrants, but for the liberal media as well. If for the media publications studied Europe stood before a moral dilemma, as the previous section showed, then these media were in a state of aporia about Europe's failure to respect its instrumental values, morals and principles and to respond to the refugee plight in a spirit of unity and humanitarianism. This was epitomised in questions such as What does it mean to be a member of the European Union? Do member states still share the values that underpinned its original foundations? (The Observer View, September 6, 2015).

The humanitarian pattern communicated is rather simple (see Douzinas 2007): there is a suffering victim, the faceless refugee or migrant; a moral rescuer that is Europe, embracing human rights and democratic values; and, occasionally, a vicious sinner (e.g. Hungary, totalitarian regimes in countries of origin). In effect, media editorials circulated a long-lasting narrative about Western values having human rights at their core (Douzinas 2007): democracy and human rights function as a last resort to persuade reluctant governments to prevent more atrocities. The problem for the studied media publications was that the moral rescuer was not adequately responding to the humanitarian challenge. In this regard, the media liberal aporia was based particularly on two beliefs, the values associated with Europe and the causes of European failure, but also on a deafening absence, the centre/periphery power relations - past and present. Therefore, the mediated expectation for a humanitarian Europe and the subsequently expressed aporia of why it had retreated from its morals should be problematised as inherently Eurocentric concepts premised on the certainty that Europe is 
based on democratic values. This strengthens the myth of the West's superiority, reinforcing the differences between 'them' and 'us' (De Genova 2017, 35), and reflects the dualisms of Eurocentrism (Quijano 2000). That the systemic nature of centre/periphery inequalities is absent is also inherently Eurocentric (Amin 2009).

The aporia about the absent Europe of values was also characterised by a sense of nostalgia for a more idealistic European past reflected, for example, in references to the "never again" campaign. But while "never again" and the Holocaust are remembered, references to Europe's and by extension the West's colonial, imperial past and neo-colonial policies were absent, at least in the data studied. The representation of Europe as a perpetrator of the crisis, found in postcolonial contexts, was missing (Avraamidou et al. 2018). Subsequently, colonialism, through its absence, formed a conundrum with the human rights discourse and the politics of humanitarianism (Douzinas 2007, 22).

This media aporia, however, is rather paradoxical given hard evidence that the European reaction was not a rupture from fair migration policies but a continuation of its pre-existing ones. Europe had long been the world's deadliest migration destination (Brian and Laczko 2014) not because of physical barriers but because of policies. References to flaws and lack of adequate measures or to the rise of populism as the causes of Europe's failure to respond to the crisis obscured institutional EU deficits, but also the role of mainstream politicians and the original EU bloc, using the words of the Guardian, in securing bordered Europe or Fortress Europe, a concept which illustrates not only the ideologies behind the European migration regime but also the institutional machinery associated with it (Ponzanesi and Blaagaard 2011, 3). In this light, Europe's and the West's long-lasting migration policies, and not only the events of 2015, constitute an exemplary case of how the "never again" promise to which the media referred was, long before, an empty promise for migrant others. The human mobility of the wretched of the earth has long been violent and unequal - a process of suffering not only because of the problems they face at home but also because of the existing migration regime that reproduces the power of coloniality. Therefore, the liberal media idealism of Europe is either a naïve or an illusionary nostalgia for a humanistic European past that never really existed. If we wish to return to a time of a humanistic Europe, then we wish for the impossible, as this past that the liberal media are nostalgic for never really existed in total, absolute terms. Notably, we can only wish for a future humanistic Europe resulting from significant, radical transformations. In covering migration using this Eurocentric humanitarian pattern, the mainstream media publications studied, and by extension other liberal media, seem to function in ways that do not contribute towards the second scenario but towards the first.

The humanitarian representation pattern shaped by Eurocentrism inevitably reproduced binaries in relation to the constructs of West and East: democratic/un-democratic, stable/unstable, master/slave, saviour/helpless, rich/poor and inclusive/divisive. Even the most pro-migrant media content reinforced these binaries as the media and journalists watched the miserable, desperate subjects of the Global South moving towards the Global North's wealthier states. However, humanitarian representation was also full of contradictions: the West relates to the positive pole of each binary in an abstract manner, but the binaries constructed also included negative connotations for the West. For example, the democratic and stable West in the face of Europe was challenged by growing xenophobia and populism. The saviour and missionary West was failing to save the helpless. The rich/master West was failing to see its interests and profit-gaining by accepting the poor/slaves. The stable West was questioned within by the former Communist countries. But these negative connotations did not unsettle 
the abstract West/East binary, as the media called Europe to rise to the challenges, reclaim its historical legacy and put an end to the ongoing atrocities. In this Eurocentric humanitarianism, the main expected rescuer of the faceless victims was specifically the democratic, liberal European states - paradoxically, the architects of Fortress Europe.

To conclude, this exploratory study of certain editorials in the NYT and the Guardian provides evidence that the European refugee crisis as a humanitarian crisis was a Eurocentric media construct. This contextualisation allowed the study to question the predominant mediated liberal humanitarian discourse that has constructed the events as a rupture, showing that it suffers from "postcolonial historical amnesia" (De Genova $2016,78)$. This article claims that by communicating the idea that the crisis was a rupture rather than a continuity of unfair, inhuman migration policies, powerful media communicate a Eurocentric perspective that banalises further the Oriental other who is once more in need of our mercy. Importantly, it is a perspective that, although sympathetic towards migrants and refugees, does not really question the migration statusquo but rather reproduces it. Future work as a continuation of this study will delineate how online users of the NYT and the Guardian read these Eurocentric representations: whether they have challenged, reproduced or re-formulated them. This is of great importance in terms of how we understand migration influences and how we react to them. Eurocentric understandings can only lead to Eurocentric reactions, which may occasionally show pity to the wretched of the earth but, overall, maintain things as they are.

\section{References}

Adorno, Theodor W. and Max Horkheimer. 1997. Dialectic of Enlightenment. London: Verso. Amin, Samir. 2009. Eurocentrism. New York: Monthly Review Press.

Askin, Dawn Kelly. 2005. "Never Again" Promise Broken Again. Again. And Again. Cardozo Law Review 27: 1723-1729.

Avraamidou, Maria, Irini Kadianaki, Maria loannou, and Elisavet Panagiotou. 2019. Representations of Europe at Times of Massive Migration Movements: A Qualitative Analysis of Greek-Cypriot Newspapers During the 2015 Refugee Crisis. Javnost-The Public 26 (1):105-119. doi.org/10.1080/13183222.2018.1505073

Baer, Alejandro and Natan Sznaider. 2015. Ghosts of the Holocaust in Franco's mass graves: Cosmopolitan memories and the politics of "never again". Memory Studies 8 (3): 328-344.

Berry, Mike, Inaki Garcia-Blanco and Kerry Moore. 2015. Press Coverage of the Refugee and Migrant Crisis in the EU: A Content Analysis of Five European Countries. Report, United Nations High Commissioner for Refugees. Accessed March 5, 2018. http://www.unhcr.org/56bb369c9.pdf

Brian, Tara and Frank Laczko. 2014. Fatal Journeys: Tracking Lives Lost during Migration. Geneva: IOM. Accessed January 31, 2020. http://lastradainternational.org//sidocs/3089FatalJourneys.pdf\#page $=87$

Braun, Virginia, and Victoria Clarke. 2006. Using Thematic Analysis in Psychology. Qualitative Research in Psychology 3 (2): 77-101.

Cashmore, Ellis. 1996. Dictionary of Race and Ethnic Relations. London: Psychology Press.

Chavez, Leo Ralph. 2001. Covering Immigration: Popular Images and the Politics of the Nation. Berkeley: University of California Press.

Chouliaraki, Lilie and Rafal Zaborowski. 2017. Voice and Community in the 2015 Refugee Crisis: a Content Analysis of News Coverage in Eight European Countries. International Communication Gazette 79 (6-7): 613-635. 
Croteau, David and William Hoynes. 2014. Media/Society: Industries, Images, and Audiences. Los Angeles: SAGE.

Davison, Sally and George Shire. 2015. Race, Migration and Neoliberalism. Soundings 59 (59): 81-95.

De Genova, Nicholas. 2017. Introduction. The Borders of "Europe" and the European Question in The Borders of "Europe": Autonomy of Migration, Tactics of Bordering, edited by Nicholas De Genova. Durham, NC: Duke University Press.

De Genova, Nicholas. 2016. The European Question: Migration, Race, and Postcoloniality in Europe. Social Text 34 (3): 75-102.

De Genova, Nicholas. 2010. Migration and Race in Europe: The Trans-Atlantic Metastases of a Post-Colonial Cancer. European Journal of Social Theory 13 (3): 405-419.

Douzinas, Costas. 2007. The Many Faces of Humanitarianism. Parrhesia 2: 1- 28.

Durham, Meenakshi Gigi. 2018. Resignifying Alan Kurdi: News Photographs, Memes, and the Ethics of Embodied Vulnerability. Critical Studies in Media Communication 35 (3): 240-258.

Dussel, Enrique. 2000. The Semantic Slippage of the Concept of "Europe". Nepantla: Views from South 1 (3): 465-478.

Fanon, Frantz. 1967. The Wretched of the Earth. London: Penguin.

Fuchs, Christian. 2019. Nationalism on the Internet: Critical Theory and Ideology in the Age of Social Media and Fake News. New York: Routledge.

Fuchs, Christian. 2016. Critical Theory of Communication. London: University of Westminster Press.

Gatt, Sabine, Kerstin Hazibar, Verena Sauermann, Max Preglau, and Michaela Ralser. 2016. Migration from a Gender-Critical, Postcolonial and Interdisciplinary Perspective. Österreichische Zeitschrift für Soziologie 41 (S3): 1-12.

Gutiérrez, Rodríguez Encarnación. 2018. The Coloniality of Migration and the "Refugee Crisis": On the Asylum-Migration Nexus, the Transatlantic White European Settler Colonialism-Migration and Racial Capitalism. Refuge 34 (1): 15-28.

Haldrup, Michael, Lasse Koefoed, and Kirsten Simonsen. 2006. Practical Orientalism: Bodies, Everyday Life and the Construction of Otherness. Geografiska Annaler: Series B, Human Geography 88 (2): 173-184.

Hall, Stuart. 1982. The Rediscovery of Ideology: Return of the Repressed in Media Studies. In Cultural Theory and Popular Culture: A Reader, edited by John Storey, 111-141. London: Longman.

Harari, Yuval Noah. 2011. Sapiens. A Brief History of Humankind. Israel: Kinneret, ZmoraBitan, Dvir.

Huggan, Graham. 2008. Perspectives on Postcolonial Europe. Journal of Postcolonial Writing 44 (3): 241-249.

Kadianaki, Irini, Maria Avraamidou, Maria Ioannou, and Elisavet Panagiotou. 2018. Understanding Media Debate Around Migration: The Relation between Favourable and Unfavourable Representations of Migration in the Greek-Cypriot Press. Peace and Conflict: Journal of Peace Psychology 24 (4): 407-416.

Khiabany, Gholam. 2016. Refugee Crisis, Imperialism and Pitiless Wars on the Poor. Media, Culture \& Society 38 (5): 755-762.

Kipling, Rudyard. 1899. The White Man's Burden. Accessed February 2, 2018. http://www.kiplingsociety.co.uk/poems burden.htm

Lazarus, Neil. 2011. What Postcolonial Theory Doesn't Say. Race \& Class 53 (1): 3-27.

Leong, Nancy. 2013. Racial Capitalism. Harvard Law Review 126: 2151-2226.

Massey, Douglas. 2000. The Social and Economic Origins of Immigration. Annals of the American Academy of Political and Social Sciences 5 (10): 60-72.

Mejia, Robert, Kay Beckermann, and Curtis Sullivan. 2018. White Lies: a Racial History of the (post)truth. Communication and Critical/Cultural Studies 15 (2): 109-126.

Melamed, Jodi. 2015. Racial capitalism. Critical Ethnic Studies 1 (1): 76-85. 
Moyn, Samuel. 2012. The last utopia: human rights in history. Harvard: Harvard University Press.

Musarò, Pierluigi. 2017. Mare Nostrum: The Visual Politics of a Military-Humanitarian Operation in the Mediterranean Sea. Media, Culture \& Society 39 (1): 11-28.

Mylonas, Yiannis. 2015. Austerity Discourses in "Der Spiegel" Magazine, 2009-2014. tripleC: Communication, Capitalism \& Critique 13 (2): 248-269. Accessed April 15, 2020. https://www.triple-c.at/index.php/tripleC/article/view/673

Ott, Brian and Robert Mack. 2014. Critical Media studies: An Introduction [2nd edition]. Chicester: John Wiley \& Sons.

Paterson, Chris. 2007. International News on the Internet: Why More is Less. Ethical Space: The International Journal of Communication Ethics 4 (1/2): 57-66.

Popescu, Alexandra. 2016. The EU "Cost" of the Refugee Crisis. Europolity 10 (1): 106-109.

Ponzanesi, Sandra and Bolette Blaagaard. 2011. In the Name of Europe. Social Identities 17 (1): 1-10.

Quijano, Anibal. 2000. Coloniality of Power and Eurocentrism in Latin America. International Sociology 15 (2): 215-232.

Rajaram, Prem Kumar. 2018. Refugees as Surplus Population: Race, Migration and Capitalist Value Regimes. New Political Economy 23 (5): 627-639. DOI:

10.1080/13563467.2017.1417372

Rheindorf, Markus and Ruth Wodak. 2018. Borders, Fences, and Limits: Protecting Austria from Refugees: Metadiscursive Negotiation of Meaning in the Current Refugee Crisis. Journal of Immigrant \& Refugee Studies 16 (1-2): 15-38.

Said, Edward. 1978. Orientalism. London: Penguin.

Sassen, Saskia. 2001. The Global City: New York, London, Tokyo. Princeton: Princeton University Press.

Siapera, Eugenia, Moses Boudourides, Sergios Lenis and Jane Suiter. 2018. Refugees and Network Publics on Twitter: Networked Framing, Affect, and Capture. Social Media + Society 4 (1). doi.org/10.1177/2056305118764437

Silverstein, Paul A. 2005. Immigrant Racialization and the New Savage Slot: Race, Migration, and Immigration in the New Europe. Annual Review of Anthropology 34: 363-384.

Suro, Roberto. 2009. Promoting Stalemate: The Media and US Policy on Migration. Washington, DC: Migration Policy Institute.

Trimikliniotis, Nicos. 2020. Migration and the Refugee Dissensus in Europe: Borders, Security and Austerity. Oxon: Routledge.

Van Dijk, Teun A. 2000. New(s) Racism: A Discourse Analytical Approach. In Ethnic Minorities and the Media, edited by Simon Cottle, 33-47. Buckingham: Open University Press.

Van Dijk, Teun A. 1995. Power and the News Media. Political Communication and Action 6 (1): 9-36.

Virdee, Satnam. 2019. Racialized capitalism: An account of its contested origins and consolidation. The Sociological Review 67 (1): 3-27.

White, Benjamin Thomas. 2019. Talk of an 'Unprecedented' Number of Refugees is wrong and dangerous. Accessed January 29, 2020. https://www.thenewhumanitarian.org/opinion/2019/10/03/unprecedented-number-refugees-wrong-dangerous?utm source=twitter\&utm medium=social\&utm campaign=social

Wodak, Ruth. 2018. Discourse and European Integration. MIM Working Paper Series 18: 1. Malmö Institute for Studies of Migration, Diversity and Welfare, Malmö University. Accessed 11 February 2018. http://muep.mau.se/bitstream/handle/2043/24699/18\%201\%20-\%20final\%20draft.pdf?sequence=2\&isAllowed=y

Young, Robert. 2001. Postcolonialism: An Historical Introduction. Malden: Blackwell Publishing.

Zaller, John R. 1992. The Nature and Origins of Mass Opinion. New York: Cambridge University Press. 


\section{About the Author}

\section{Maria Avraamidou}

Maria Avraamidou is a post-doctoral research fellow, Department of Psychology, University of Cyprus. Her research interests revolve around the media/nationalism and the media/migration nexus. She has published peer-reviewed articles and research reports on these issues and continues researching the interconnections between traditional media and social media with a focus on nationalistic and racialised representations, taking a critical approach. 